\title{
In vitro antioxidant and anti-HIV-1 protease (PR) activities of two Clusiaceae plants endemic to Tanzania
}

\author{
J. JANGU MAGADULA ${ }^{1 *}$, S. TEWTRAKUL ${ }^{2}$, J. GATTO $^{3}$ and P. RICHOMME ${ }^{3}$ \\ ${ }^{1}$ Institute of Traditional Medicine, Muhimbili University of Health and Allied Sciences, P.O. Box 65001, Dar es \\ Salaam, Tanzania. \\ ${ }^{2}$ Department of Pharmacognosy and Pharmaceutical Botany, Faculty of Pharmaceutical Sciences, Prince of \\ Songkla University, Hat-Yai, Songkhla, 90112, Thailand. \\ ${ }^{3}$ SONAS-UFR Sciences Pharmaceutiques, 16 Bd Daviers, F-49100 Angers, France. \\ *Corresponding author, E-mail: magadulajanguj@yahoo.com ; Tel: +255 754568702.
}

Fax: +25522 2150465 .

\begin{abstract}
In this study, the ethanol extracts from Allanblackia ulugurensis Engl. and Mammea usambarensis Verdc. were evaluated for their antioxidant and anti-HIV PR activities. Among the tested extracts, the stem bark extract of M. usambarensis showed the highest DPPH activity value of $6,165 \pm 152 \mu \mathrm{mol} \mathrm{TE} / \mathrm{g}$, which is more than twice as higher as that of the standard (Chlorogenic acid, 3,056 $\pm 157 \mu \mathrm{mol} \mathrm{TE} / \mathrm{g}$ ). Furthermore, in the Oxygen Radical Absorbance Capacity (ORAC) assay, the crude extracts of the stem bark of $M$. usambarensis and root bark of A. ulugurensis showed significant activity at 12,282 \pm 413 and 10,342 \pm 562 $\mu \mathrm{mol} \mathrm{TE} / \mathrm{g}$ respectively with standard compound (Chlorogenic acid) showing ORAC activity at 11,077 \pm 236 $\mu \mathrm{mol} \mathrm{TE} / \mathrm{g}$. For anti-HIV-1 PR assay from the same extracts, the root bark and stem bark of A. ulugurensis showed strong inhibitory activities against HIV-1 protease with $\mathrm{IC}_{50}$ values of 4.1 and $5.6 \mu \mathrm{g} / \mathrm{ml}$, respectively while that of the standard, Acetyl pepstatin, was at $2.2 \mu \mathrm{g} / \mathrm{ml}$. This study has shown the potential of the Clusiaceae extracts as the source of possible lead compounds for antioxidants and anti-HIV drugs. Phytochemical screening indicated the presence of phenolic compounds while isolation of active principles from active fractions is inevitable.
\end{abstract}

(C) 2011 International Formulae Group. All rights reserved.

Keywords: A. ulugurensis, M. usambarensis, Antioxidant and anti-HIV activities, Phytochemical screening

\section{INTRODUCTION}

Plants have for so long shown to be important in the human diet as well as in health maintenance. The well known beneficial role provided by plants is protection against cellular damage caused by exposure to high levels of free radicals that include reactive oxygen species (ROS) such as hydrogen peroxide $\left(\mathrm{H}_{2} \mathrm{O}_{2}\right)$, singlet oxygen $\left({ }^{1} \mathrm{O}_{2}\right)$, superoxide anion radical $\left(\mathrm{O}_{2}^{-}\right)$and hydroxyl radical $(\mathrm{OH})$ (Aruoma, 1996). Different parts of Clusiaceae plant species are known to contain high levels of antioxidant compounds such as polyphenols, phenolic acids, flavonoids, and carotenoids (Wang and Lin, 2000). These antioxidants are thought to 
prevent chronic complications in part through their interactions with ROS and ability to scavenge free radicals (Seifried et al., 2007).

On the other hand, an acquired immunodeficiency syndrome (AIDS) has evolved rapidly into an epidemic and has caused a world-wide health crisis. Considerable research has been carried out to discover compounds as anti-HIV-1 agents and as enzyme inhibitors of the HIV-1. However, there is still demand for newer, more effective treatment of this disease since HIV-1 is resistant to several synthetic HIV-1 protease (PR) inhibitors. The viral enzyme HIV-1 PR hydrolyzes viral polyproteins into functional enzymes and structural proteins that are essential for viral assembly (Katz and Skalka, 1984). Thus, searching for HIV-1 PR inhibitors from natural sources is becoming a good approach. Recent studies on extracts and compounds from Clusiaceae plant species, native to Tanzania have shown noticeable activity against HIV protease activity and HIV-1 viral replication in MT4 cells (Magadula \& Tewtrakul, 2010; Magadula \& Suleiman, 2010). The potential beneficial effects attributed to Clusiaceae extracts are believed to be related to abundance of phenolic compounds found in these plants (Lenta et al., 2007). This study reports the evaluation of ethanol crude extracts of $A$. ulugurensis and $M$. usambarensis for antioxidants and HIV-1 protease activities as well as the phytochemical screening of extracts aiming to establish the classes of compounds responsible for the biological activities.

\section{MATERIALS AND METHODS}

\section{Chemicals}

1,1-Diphenyl-2-picrylhydrazyl (DPPH) was purchased from Sigma Aldrich (L'Isle d'Abeau Chesnes, France). 6-Hydroxy2,5,7,8-tetramethylchroman-2-carboxylique acid $\quad\left(\right.$ Trolox $\left.^{\circledR}\right), \quad 5^{\prime}$-caffeoylquinic acid (Chlorogenic acid), 2,2'-Azobis (2- methylpropionamidine) dihydrochloride (AAPH) and fluorescein (FL) were obtained from Acros Organics (Illkirch, France).

\section{Sample preparation}

Ten grams (powder) of the specified part of each dried plant material was soaked in ethanol $(150 \mathrm{ml})$ for $48 \mathrm{~h}$ at room temperature. The ethanol extract was filtered and evaporated under vacuum on a rotary evaporator. The crude extracts were dissolved in DMSO for bioassay.

\section{DPPH scavenging activity}

The DPPH radical scavenging effects of M. usambarensis and A. ulugurensis were carried out using a modified previously established methodology (Abdel-Lateff et al., 2002). In its radical form, $\mathrm{DPPH}^{\circ}$ has an absorption band at $517 \mathrm{~nm}$ which disappears upon reduction by an antiradical compound. The tested extracts and standards were diluted in absolute ethanol at $0.02 \mathrm{mg} / \mathrm{ml}$ from stock solutions at $1 \mathrm{mg} / \mathrm{ml}$ in DMSO. $100 \mu \mathrm{l}$ aliquots of these diluted solutions were placed in 96-well plates in triplicates. The reaction was initiated by adding $25 \mu \mathrm{l}$ of freshly prepared DPPH solution $(1 \mathrm{mM})$ and $75 \mu \mathrm{l}$ of absolute ethanol using the microplate reader's injector (Infinite ${ }^{\circledR}$ 200, Tecan, France) to obtain a final volume of $200 \mu \mathrm{l}$ per well. After 30 minutes in the dark and at room temperature, the absorbance was determined at $517 \mathrm{~nm}$. Ethanol was used as a blank, whereas $10,25,50$, and $75 \mu \mathrm{M}$ of Trolox (hydrophilic $\alpha$-tocopherol analog) were used as calibration solutions. A sample of 0.02 $\mathrm{mg} / \mathrm{ml}$ chlorogenic acid was used as a quality control. The DPPH-scavenging activity of tested compounds was compared with that of Trolox calibration curve. Results were expressed in terms of Trolox equivalent (micromoles of Trolox equivalents per gram of dry matter). 


\section{Oxygen radical absorbance capacity (ORAC)}

ORAC assays were carried out according to the method of Huang et al. (2002) with some modifications. This assay measures the ability of antioxidant compounds to inhibit the decline in fluorescein (FL) fluorescence that is induced by a peroxyl radical generator namely 2,2'-azobis(2methylpropionamidine) dihydrochloride (AAPH). The assay was performed in a 96well plate. The reaction mixture contained 100 $\mu \mathrm{l}$ of $75 \mathrm{mM}$ phosphate buffer (pH 7.4), 100 $\mu \mathrm{l}$ of freshly prepared FL solution $(0.1 \mu \mathrm{M}$ in phosphate buffer), $50 \mu \mathrm{l}$ of freshly prepared AAPH solution $(51.6 \mathrm{mg} / \mathrm{ml}$ in phosphate buffer), and $20 \mu \mathrm{l}$ of sample per well. Samples were analysed in triplicates and diluted at different concentrations $(25 \mu \mathrm{g} / \mathrm{ml}, 12.5$ $\mu \mathrm{g} / \mathrm{ml}, 6.25 \mu \mathrm{g} / \mathrm{ml}$ and $3.12 \mu \mathrm{g} / \mathrm{ml}$ ) from stock solutions at $1 \mathrm{mg} / \mathrm{ml}$ in DMSO. FL, phosphate buffer, and samples were preincubated at 37 ${ }^{\circ} \mathrm{C}$ for $10 \mathrm{~min}$. The reaction was started by the addition of AAPH using the microplate reader's injector (Infinite ${ }^{\circledR}$ 200, Tecan, France). Fluorescence was then measured and recorded during 40 minutes at excitation and emission wavelengths of 485 and $520 \mathrm{~nm}$ respectively. The $75 \mathrm{mM}$ phosphate buffer was used as a blank, and 12.5, 25, 50, and 75 $\mu \mathrm{M}$ of Trolox (hydrophilic $\alpha$-tocopherol analog) were used as calibration solutions. A sample of $8.8 \mu \mathrm{M}$ chlorogenic acid was used as a quality control. The final ORAC values were calculated by using a regression equation between the Trolox concentration and the net area under the FL decay curve and were expressed as micromoles of Trolox equivalents per gram of dry matter. The area under curve was calculated using Magellan ${ }^{\mathrm{TM}}$ data analysis software (Tecan, France).

\section{HIV-1 PR inhibitory activity}

This assay was modified from the previously reported method (Tewtrakul et al., 2003). In brief, the recombinant HIV-1 PR solution was diluted with a buffer composed of a solution containing $50 \mathrm{mM}$ of sodium acetate ( $\mathrm{pH}$ 5.0), $1 \mathrm{mM}$ ethylenediamine disodium (EDTA.2Na) and $2 \mathrm{mM}$ 2mercaptoethanol (2-ME) and mixed with glycerol in the ratio of $3: 1$. The substrate peptide, Arg-Val-Nle-( $\mathrm{pNO}_{2-}$ Phe)-Glu-Ala$\mathrm{Nle}-\mathrm{NH}_{2}$, was diluted with a buffer solution of $50 \mathrm{mM}$ sodium acetate $(\mathrm{pH}$ 5.0). Two microliters of plant extract and $4 \mu \mathrm{l}$ of HIV-1 PR solution $(0.025 \mathrm{mg} / \mathrm{mL})$ were added to a solution containing $2 \mu \mathrm{l}$ of $50 \mathrm{mM}$ buffer solution ( $\mathrm{pH} 5.0$ ) and $2 \mu \mathrm{l}$ of substrate solution $(2 \mathrm{mg} / \mathrm{ml})$, and the reaction mixture $(10 \mu \mathrm{l})$ was incubated at $37^{\circ} \mathrm{C}$ for $1 \mathrm{~h}$. A control reaction was performed under the same conditions but without the plant extract. The reaction was stopped by heating the reaction mixture at $90^{\circ} \mathrm{C}$ for $1 \mathrm{~min}$. Subsequently, $20 \mu \mathrm{l}$ of sterilized water was added and an aliquot of $10 \mu \mathrm{l}$ was analyzed by HPLC using RP-18 column (4.6 x $150 \mathrm{~mm}$ I.D., Supelco 516 C-18-DB 5 mm, USA). Ten microlitres of the reaction mixture was injected to the column and gradiently eluted with acetonitrile (15-40\%) and $0.2 \%$ trifluoroacetic acid (TFA) in water, at a flow rate of $1.0 \mathrm{ml} / \mathrm{min}$. The elution profile was monitored at $280 \mathrm{~nm}$. The retention times of the substrate and $\mathrm{p}-\mathrm{NO}_{2}$-Phe-bearing hydrolysate were 11.25 and $9.72 \mathrm{~min}$, respectively. The inhibitory activity on HIV-1 PR was calculated as follows: $\%$ inhibition = $\left(\mathrm{A}_{\text {control }}-\mathrm{A}_{\text {sample }}\right) \times 100 / \mathrm{A}_{\text {control }}$ where $\mathrm{A}$ is a relative peak area of the product hydrolysate. Acetyl pepstatin was used as a positive control.

\section{Phytochemical screening test for the extracts}

The methods of Trease and Evans (1983) and Harbourne (1983) to test for alkaloids, tannins, flavonoids, steroids and saponins were used.

\section{Statistical analysis}

Data were presented as means \pm SD. Statistical analysis was conducted using the 
SPSS 12.0 statistical package (Chicago, IL, USA). Data were subjected to analysis of variance, and means were separated using Fisher's least significant difference (LSD) test at $\mathrm{P}=0.05$. Pearson correlation analysis was used to evaluate the relationships among the variables of interest. A p-value of less than 0.05 was considered statistically significant. The results of anti-HIV-1 PR activity were expressed as means $\pm \mathrm{SD}$ of three determinations. The $\mathrm{IC}_{50}$ values were calculated using the Microsoft Excel programme.

\section{RESULTS}

DPPH is a simple and rapid assay which has been used extensively as a prescreening method to reveal new antioxidants from natural sources (Chen et al., 2008). In its radical form, $\mathrm{DPPH}^{*}$ has an absorption band at $517 \mathrm{~nm}$, which disappears upon reduction by an antiradical compound/extract. Thus, the spectrophotometrical measure of the absorbance reflects the antioxidant potential of the molecule tested.

Radical scavenging potentials of $A$. ulugurensis and $M$. usambarensis species were first tested using DPPH radical method and results are presented in Table 1. Among the different extracts of A. uluguruensis tested, root and stem extracts exhibited the most effective scavenging ability on DPPH free radicals (5126 and $5493 \mu \mathrm{mol} \mathrm{TE} / \mathrm{g}$ respectively). The activity of fruit extract was slightly lower (2874 $\mu \mathrm{mol} \mathrm{TE} / \mathrm{g})$ but still similar to that of the pure compound/reference chlorogenic acid (3056 $\mu \mathrm{mol} \mathrm{TE} / \mathrm{g})$. The same trend could be observed for M. usambarensis, where root and stem extracts showed the greatest DPPH value (5856 and $6165 \mu \mathrm{mol}$ TE/g respectively), whilst leaf extract presented the lowest value $(2241 \mu \mathrm{mol} \mathrm{TE} / \mathrm{g})$ (Table 1).

Further evaluation of the antioxidant activity of $A$. ulugurensis and $M$. usambarensis species was conducted by an
ORAC assay. Taking chlorogenic acid as the reference compound, the net ORAC values determined from the area under the fluorescence decay curves are collected in Table 1. Those data correlate well with the DPPH values. Root and stem extracts of $A$. ulugurensis have approximately the same ORAC value (10342 and $9622 \mu \mathrm{mol} \mathrm{TE} / \mathrm{g}$ respectively). These extracts are more active than fruit extract (1928 $\mu \mathrm{mol} \mathrm{TE} / \mathrm{g})$ (Table 1). As in A. ulugurensis, root and even more stem parts of $M$. usambarensis presented the higher ORAC values (6841 and $12282 \mu \mathrm{mol} \mathrm{TE} / \mathrm{g}$ respectively). Leaf extract presented a lower ORAC value $(2733 \mu \mathrm{mol} \mathrm{TE} / \mathrm{g})$ than root and stem parts.

Furthermore, Figure 1 shows the fluorescence decay curves, resulting from the incubation of fluorescein in presence of $\mathrm{AAPH}$, both in the absence and the presence of increasing concentrations of Trolox (calibration curve, Fig. 1a) or A. ulugurensis root extract (Fig. 1b). Hence, the inserts show the linear correlation between the net area under the curve and the analytes concentrations. The linearity between the net area under the curve (AUC-AUC ${ }^{0}$ ) and the concentration was tested for all extracts (Table 2). For each extract, solutions of concentration within the linearity range gave relatively similar ORAC values.

In the anti-HIV assay, results showed that the root and stem barks of A. ulugurensis possessed good anti-HIV-1 activity with $\mathrm{IC}_{50}$ values of 4.1 and $5.6 \mu \mathrm{g} / \mathrm{ml}$, respectively (Table 3); whereas that of a positive control, acetyl pepstatin, was found to be $2.2 \mu \mathrm{g} / \mathrm{ml}$. Other plant parts also exhibited appreciable good effects against HIV-1 PR with $\mathrm{IC}_{50}$ values ranging from 12.2-14.2 $\mu \mathrm{g} / \mathrm{ml}$ (Table 3).

The phytochemical screening results on A. ulugurensis and M. usambarensis indicated the presence of mainly phenolic compounds, phytosterols and saponins (Table 4). 
Table 1: DPPH and ORAC antioxidant activities of A. uluguruensis and M. usambarensis extracts.

\begin{tabular}{lccr}
\hline Plant species & $\begin{array}{c}\text { Part } \\
\text { (extracted in ethanol) }\end{array}$ & $\begin{array}{c}\text { DPPH }^{\mathbf{a}} \\
(\boldsymbol{\mu} \mathbf{m o l ~ T E} / \mathbf{g})\end{array}$ & \multicolumn{1}{c}{$\begin{array}{c}\text { ORAC }^{\mathbf{b}} \\
(\boldsymbol{\mu} \mathbf{m o l ~ T E} / \mathbf{g})\end{array}$} \\
\hline A. ulugurensis & Root & $5,126 \pm 224$ & $10,342 \pm 562$ \\
& Stem & $5,493 \pm 177$ & $9,622 \pm 780$ \\
& Fruit & $2,874 \pm 175$ & $1,928 \pm 130$ \\
\hline M. usambarensis & Root & $5,856 \pm 446$ & $6,841 \pm 167$ \\
& Stem & $6,165 \pm 152$ & $12,282 \pm 413$ \\
& Leaf & $2,241 \pm 109$ & $2,733 \pm 100$ \\
\hline Chlorogenic acid (Standard) & & $3,056 \pm 157$ & $11,077 \pm 00$
\end{tabular}

$*$ Antioxidant activities were expressed as means \pm SD of three determinations, a = 1,1-Diphenyl-2-picrylhydrazyl; $b=$ Oxygen Radical Absorbance Capacity

Table 2: Linear ranges (net AUC versus concentration) of A. uluguruensis and M. usambarensis extracts.

\begin{tabular}{llcccc}
\hline Plant species & Part & $\begin{array}{c}\text { Concentration } \\
\text { range }(\boldsymbol{\mu} \mathbf{g} / \mathbf{m l})\end{array}$ & slope & intercept & $\boldsymbol{r}^{\mathbf{2}}$ \\
\hline A. ulugurensis & Root & $3.13-25.0$ & $1.9 \mathrm{E}+06$ & $7.8 \mathrm{E}+06$ & 0.9869 \\
& Stem & $1.56-12.5$ & $2.0 \mathrm{E}+06$ & $4.5 \mathrm{E}+06$ & 0.9791 \\
& Fruit & $1.56-25.0$ & $9.0 \mathrm{E}+05$ & $1.5 \mathrm{E}+06$ & 0.9995 \\
\hline M. usambarensis & Root & $1.56-12.5$ & $2.1 \mathrm{E}+06$ & $2.7 \mathrm{E}+06$ & 0.9828 \\
& Stem & $3.13-25.0$ & $1.3 \mathrm{E}+06$ & $1.4 \mathrm{E}+07$ & 0.9636 \\
& Leaf & $1.56-12.5$ & $1.2 \mathrm{E}+06$ & $1.5 \mathrm{E}+06$ & 0.9995 \\
\hline
\end{tabular}

Table 3: Anti-HIV-1 protease activity of A. uluguruensis and M. usambarensis extracts.

\begin{tabular}{|c|c|c|c|c|c|c|}
\hline \multirow[t]{2}{*}{ Plant species } & \multirow[t]{2}{*}{ Part } & \multicolumn{5}{|c|}{$\%$ Inhibition at various concentrations $(\mu \mathrm{g} / \mathrm{ml})$} \\
\hline & & 3 & 10 & 30 & 100 & $\mathrm{IC}_{50}(\mu \mathrm{g} / \mathrm{ml})$ \\
\hline & Root & $51.7 \pm 0.4$ & $86.3 \pm 0.2$ & $89.8 \pm 0.2$ & $90.2 \pm 0.1$ & 4.1 \\
\hline \multirow{2}{*}{ ulugurensis } & Stem & $39.1 \pm 0.9$ & $81.4 \pm 0.3$ & $86.3 \pm 0.2$ & $92.2 \pm 0.1$ & 5.6 \\
\hline & Fruit & $-3.1 \pm 1.0$ & $53.1 \pm 0.8$ & $66.9 \pm 0.7$ & $67.9 \pm 0.5$ & 13.8 \\
\hline & Root & $-1.6 \pm 0.4$ & $60.5 \pm 0.6$ & $73.93 \pm 0.5$ & $90.0 \pm 0.2$ & 12.2 \\
\hline \multirow[t]{2}{*}{ usambarensis } & Stem & $12.5 \pm 0.3$ & $52.3 \pm 0.6$ & $68.9 \pm 0.5$ & $81.6 \pm 0.3$ & 14.2 \\
\hline & Leaf & $-6.1 \pm 0.9$ & $61.8 \pm 0.6$ & $66.8 \pm 0.4$ & $68.8 \pm 0.5$ & 12.8 \\
\hline \multicolumn{2}{|c|}{ Acetyl pepstatin (+ve control) } & $50.2 \pm 1.4$ & $70.0 \pm 0.5$ & $82.4 \pm 0.4$ & $88.5 \pm 0.2$ & 2.2 \\
\hline
\end{tabular}

Table 4: Phytochemical screening of ethanol extracts from A. ulugurensis and M. usambarensis.

\begin{tabular}{|c|c|c|c|c|c|c|}
\hline \multirow[t]{2}{*}{ Plant name } & \multirow[t]{2}{*}{ Part } & \multicolumn{5}{|c|}{ Class of compounds tested } \\
\hline & & Phytosterols & Alkaloids & Phenolics & Saponins & Tannins \\
\hline \multirow[t]{3}{*}{ A. ulugurensis } & Root & + & - & +++ & + & - \\
\hline & Stem & + & - & ++ & - & + \\
\hline & Fruit & - & - & + & - & - \\
\hline \multirow[t]{3}{*}{ M. usambarensis } & Root & + & - & +++ & - & - \\
\hline & Stem & + & - & +++ & & - \\
\hline & Leaf & + & - & + & + & + \\
\hline
\end{tabular}


(a)

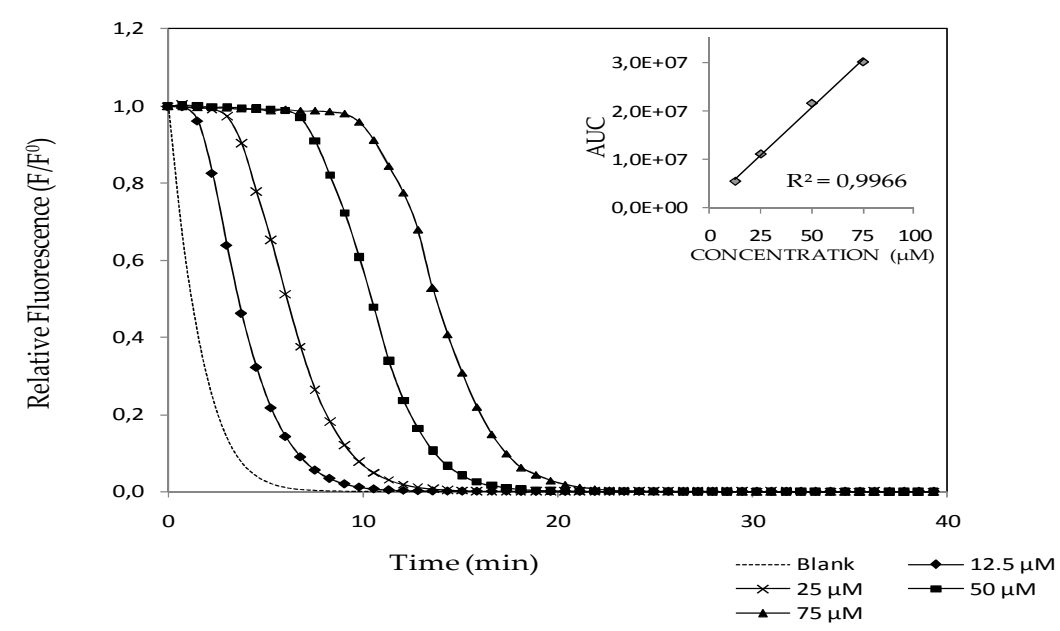

(b)

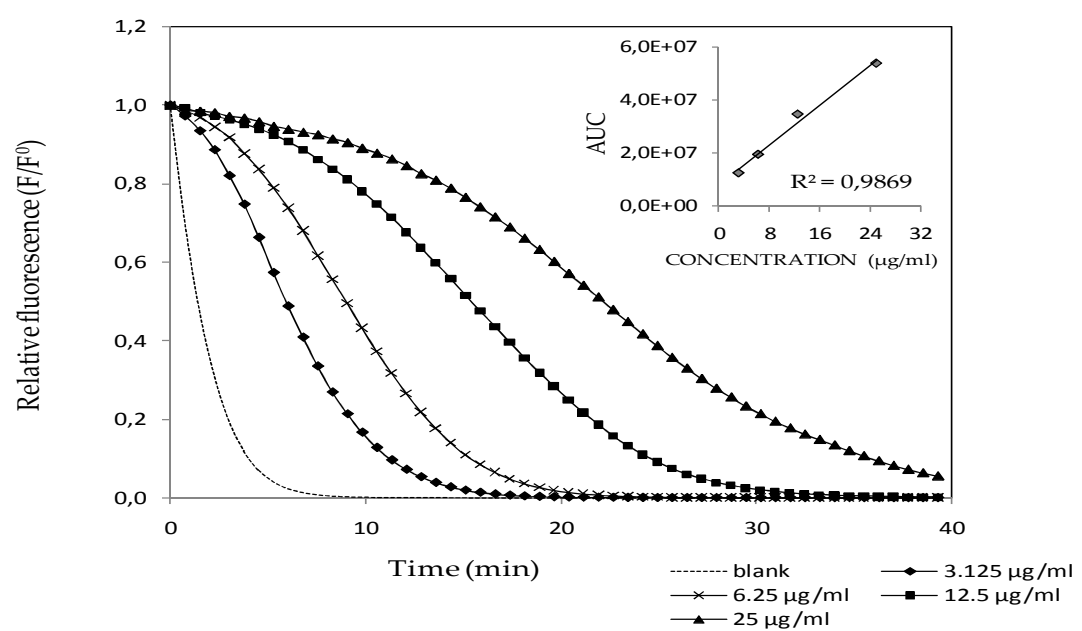

Figure 1: Fluorescein fluorescence decay curves induced by AAPH in the presence of (a) Trolox and (b) A. ulugurensis root extract, at different concentrations.

\section{DISCUSSION}

Since multiple reaction characteristics and mechanisms are involved in the so-called oxidative stress, using a single test is not sufficient to evaluate the antioxidant potential of plant natural compounds or extracts (Prior et al., 2005). Therefore, two antioxidant assays, DPPH radical scavenging activity and ORAC methods were chosen in order to examine the different extracts of $A$. ulugurensis and M. usambarensis species. As far as Clusiaceaes species are concerned and because of many different units used in DPPH radical scavenging activities reports, direct comparison with literature data is not always possible. However, in agreement with our results, Ayoola et al. (2008) observed in a previous study of Allanblackia floribunda that a methanol extract from the leaves exhibited a higher DPPH free radical scavenging activity when compared with fruit extract. They also highlighted the contribution of total flavonoid and proanthocyanidin content in this difference of activity.

On the other hand, the ORAC assay has the advantage of combining both inhibition 
times and degrees of inhibition of the reactive species measurements into a single quantity (Huang et al., 2002). Moreover, this method is based upon a reaction mechanism provoked by peroxyl radicals that represent predominant reactive species of oxygen in biological systems. However, the ORAC value obtained for fruit extract of A. ulugurensis was higher than those reported in literature for various fruit or seed extracts, including $50 \%$ acetone extract of strawberry $(542 \mu \mathrm{mol} \mathrm{TE} / \mathrm{g}$ ) (Huang et al., 2002) and $80 \%$ ethanol extract of blackberry $(674.2 \mu \mathrm{mol} \mathrm{TE} / \mathrm{g}$ ) (Elisia et al., 2007), but still equivalent to or lower than methanol extracts of pummelo and navel orange $(2220$ and $1940 \mu \mathrm{mol} \quad \mathrm{TE} / \mathrm{g}$ respectively) (Jayaprakasha et al., 2008) and $50 \%$ acetone extract of elderberry, bilberry and grape seeds (2221, 2646 and $11889 \mu \mathrm{mol}$ $\mathrm{TE} / \mathrm{g}$ respectively) (Ou et al., 2001).

In Mammea genus, antioxidant activity has been studied particularly in flower buds of Mammea longifolia, a Clusiaceae plant largely used in India as a minor spice (Rao et al., 2004 ; Rathee et al., 2006). But to the best of our knowledge, there is no other Mammea species that have been screened for their antioxidant activity. The stem extract of $M$. usambarensis showed a very good potency with an ORAC value which can be compared with the one of a $50 \%$ acetone extract of rosemary described by Huang et al. (2002) (14300 $\mu \mathrm{mol} \mathrm{TE} / \mathrm{g}$ ). However, the literature survey reveals a high variability between ORAC activities obtained for various rosemary extracts depending on extraction solvent, procedure or starting material (14300 $\mu \mathrm{mol} \mathrm{TE} / \mathrm{g}$ (Huang et al., 2002); $2800 \mu \mathrm{mol}$ TE/g (Tsai et al., 2008); $4360 \mu \mathrm{mol} \mathrm{TE/g} \mathrm{(Ho}$ et al., 2008). In comparison to ORAC values reported in literature for leaf parts, $M$. usambarensis leaf extract was higher than a $50 \%$ acetone extract of spinach (Ou et al., 2002) but still lower than a methanolic extract of green tea $(4630 \mu \mathrm{mol} \mathrm{TE} / \mathrm{g})$ described by Tsai et al. (2008). This suggests that $M$. usambarensis is an exceptional source of natural antioxidants and hence the plant may provide potential antioxidant protection, thereby promoting good health for human beings.

The anti-HIV results exhibited by the root and stem barks of A. ulugurensis, with $\mathrm{IC}_{50}$ values of 4.1 and $5.6 \mu \mathrm{g} / \mathrm{ml}$ respectively (Table 3), suggest this plant to have a potential to be developed as an anti-HIV-1 agents. Previous phytochemical work reports the presence of xanthones, benzophenones, biflavonoids and coumarins from different plants of the family Clusiaceae possessing anti-HIV activity (Gustafson et al., 1992; Mahidol et al., 2002; Ma et al., 2008). It is therefore believed that the potential bioactivities noted in this study may have been contributed by these classes of compounds. Hence, the isolation of active compounds from these plants is inevitable.

\section{Conclusion}

Proper exploitation of A. ulugurensis and $M$. usambarensis can lead into useful phytomedicines/compounds to combat oxidative stresses and HIV problems. However, by studying extracts, we can not rule out the possibility of a synergistic interaction between compounds that could cause a marked increase in antioxidant and anti-HIV activities. Hence, this preliminary study of antioxidant and anti-HIV activities of A. ulugurensis and M. usambarensis extracts sets as a base for a bioassay-guided isolation and purification of compounds of interest.

\section{ACKNOWLEDGEMENTS}

The authors wish to thank Mr. Haji O. Suleiman of the Botany Department, Faculty of Pharmaceutical Sciences, University of Dar es Salaam, Tanzania for collection and identification of the plant materials; Prince of Songkla University, Songkhla, Thailand for HIV-1 PR testing and the Laboratoire des Substances d'origine naturelle et analogues structuraux (SONAS), Université Angers, France for antioxidant testing. This study was supported by SIDA-SAREC Research Capacity Strengthening Grant (extended to JJM) under the Muhimbili University of Health and Allied Sciences, Tanzania. 


\section{REFERENCES}

Abdel-Lateff A, König GM, Fisch KM, Höller U, Jones PG, Wright AD. 2002. New antioxidant hydroquinone derivatives from the algicolous marine fungus. $J$. Nat. Prod., 65: 1605-1611.

Aruoma OI. 1996. Assessment of potential prooxidant and antioxidant actions. J. Am. Oil Chem. Soc., 73: 1617-1625.

Ayoola GA, Ipav S S, Sofidiya MO, AdepojuBello AA, Coker HAB, Odugbemi TO. 2008. Phytochemical screening and free radical scavenging activities of the fruits and leaves of Allanblackia floribunda Oliv (Guttiferae). Int. J. Health Res., 1: 87-93.

Elisia I, Hu C., Popovich DG, Kitts DD. 2007. Antioxidant assessment of an anthocyanin-enriched blackberry extract. Food Chem., 101: 1052-1058.

Gustafson KR, Blunt JW, Munro MHG, Fuller RW, Mckee TC, Cardellina JH II, McMahon JB, Cragg GM, Boyd MR. 1992. The guttiferones, HIV-inhibitory benzophenones from Symphonia globulifera, Garcinia livingstonei, Garcinia ovalifolia and Clusia rosea. Tetrahedron., 48: 10093-10102.

Harbourne JB. 1983. Phytochemical Methods: A Guide to Modern Technique of plants Analysis. Chapman and Hall: London.

Huang D, Ou B, Hampsch-Woodill M, Flanagan JA, Prior RL. 2002. Highthroughput assay of oxygen radical absorbance capacity (ORAC) using a multichannel liquid handling system coupled with a microplate fluorescence reader in 96-well format. J. Agric. Food Chem., 50: 4437-4444.

Jayaprakasha GK, Girennavar B, Patil BS. 2008. Antioxidant capacity of pummel and navel oranges: Extraction efficiency of solvents in sequence. LWT-Food Sci Technol., 41: 376-384.

Katz RA, Skalka, AM. 1994. The retroviral enzymes. Annual Review of Biochemistry, 63: 133-173.
Lenta NB, Vonthron-Sénécheau C, Weniger B, Devkota KP, Ngoupayo J, Kaiser M, Naz Q, Choudhary MI, Tsamo E, Sewald N. 2007. Leishmanicidal and cholinesterase inhibiting activities of phenolic compounds from Allanblackia monticola and Symphonia globulifera. Molecules, 12: 1548-1557.

Ma T, Gao Q, Chen Z, Wang L, Liu G. 2008. Chemical resolution of calanolide $\mathrm{A}$, cordatolide A and their 11-demethyl analogues. Biol. Med. Chem. Lett. 18: 1079-1083.

Magadula JJ, Tewtrakul S. 2010. Anti-HIV-1 protease activities of crude extracts of some Garcinia species Growing in Tanzania. African J. Biotechnol., 9: 18481852.

Magadula JJ, Suleiman HO. 2010. Cytotoxic and anti-HIV activities of some Tanzanian Garcinia species. Tanz. J. Health Res., 12: 1-6.

Mahidol C., Kaweetripob W, Prawat H, Ruchirawat S. 2002. Mammea coumarins from the flowers of Mammea siamensis. J. Nat. Prod., 65: 757-760.

Ou B, Huang D, Hampsch-Woodill M, Flanagan JA, Deemer EK. 2002. Analysis of antioxidant activities of common vegetables employing oxygen radical absorbance capacity (ORAC) and ferric reducing antioxidant power (FRAP) assays: A comparative study. J. Agric. Food Chem., 50: 3122-3128.

Prior RL, Wu X, Schaich K. 2005. Standardized methods for the determination of antioxidant capacity and phenolics in foods and dietary supplements. J. Agric. Food Chem., 53: 4290-4302.

Rao LJM, Yada H, Ono H, OhnishiKameyama M, Yoshida M. 2004. Occurrence of antioxidant and radical scavenging proanthocyanidins from the Indian minor spice nagkesar (Mammea longifolia planch and triana syn). Bioorg. Med. Chem., 12: 31-36. 
Rathee JS, Hassarajani SA, Chattopadhyay S. 2006. Antioxidant activity of Mammea longifolia bud extracts. Food Chem., 99: 436-443.

Seifried HE, Anderson DE, Fisher EI, Milner JA. 2007. A review of the interaction among dietary antioxidants and reactive oxygen species. J. Nutri. Biochem, 18: $567-579$.

Tewtrakul S, Subhadhirasakul S, Kummee S. 2003. HIV-1 protease inhibitory effects of medicinal plants used as self medication by AIDS patients. Songklanakarin J. Sci. Technol, 25: 239-243.
Trease GE, Evans WC. 1983. Pharmacognosy (14th Edn). Publ. Brown Publications.

Tsai TH, Chien YC, Lee CW, Tsai PJ. 2008. In vitro antimicrobial activities against cariogenic streptococci and their antioxidant capacities: A comparative study of green tea versus different herbs. Food Chem., 110: 859-864.

Wang SY, Lin HS. 2000. Antioxidant activity in fruits and leaves of blackberry, raspberry, and strawberry varies with cultivar and developmental stage. $J$. Agric. Food Chem., 48: 140-146. 